The Philosophical Journal of Conflict and Violence

Vol. II, Issue 2/2018

(C) The Authors 2018

Available online at http://trivent-publishing.eu/

\title{
The Long Walk: Stephen King's Near-Future Critique of Sport and Contemporary Society
}

\author{
Fred Mason \\ Faculty of Kinesiology (University of New Brunswick), Canada, fmason@unb.ca
}

\begin{abstract}
Stephen King's novel The Long Walk, written under the pseudonym of Richard Bachman, offers a vision of sport in a near-future society, where death-sports serve as a major spectacle. This was designed as a critique of trends and problems in sport in the 1960s and 1970s, with over-commercialization and increased violence. Some of this has been mitigated by recent rule changes in the world of sport, but King's writing prefigured the rise of reality television, where people are practically willing to risk it all for personal gain.
\end{abstract}

Keywords: Richard Bachman; Stephen King; Sport literature; science fiction; violence.

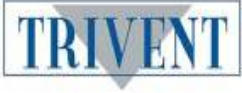

The PJCV Journal is published by Trivent Publishing.

This is an Open Access article distributed in accordance with the Creative Commons Attribution Non Commercial (CC-BY-NC-ND 4.0) license, which permits others to copy or share the article, provided original work is properly cited and that this is not done for commercial purposes. Users may not remix, transform, or build upon the material and may not distribute the modified material (http:/ / creativecommons.org/ licenses/by-nc/4.0/) 


\title{
The Long Walk: Stephen King's Near-Future Critique of Sport and Contemporary Society
}

\author{
Fred Mason \\ Faculty of Kinesiology (University of New Brunswick) \\ Canada,fmason@unb.ca
}

\begin{abstract}
Stephen King's novel The Long Walk, written under the pseudonym of Richard Bachman, offers a vision of sport in a near-future society, where death-sports serve as a major spectacle. This was designed as a critique of trends and problems in sport in the 1960s and 1970s, with over-commercialization and increased violence. Some of this has been mitigated by recent rule changes in the world of sport, but King's writing prefigured the rise of reality television, where people are practically willing to risk it all for personal gain.
\end{abstract}

Keywords: Richard Bachman; Stephen King; Sport literature; science fiction; violence.

\section{Introduction}

Writing as Richard Bachman, Stephen King produced two novels that offered a glimpse of a near-future world where sport-like activities took a central place in society, both feeding into and expressing the degeneration of social relations and concern for the welfare of the people. Bachman's vision of sport and game shows of the future that appear in The Long Walk and The Running Man suggest a "post-sport" period, where competition takes a back seat to spectacle, and the ultimate spectacle, as in ancient Rome's Colloseum, is the death of the competitors. These novels, deeply concerned with the state of the world and the state of sport in the late 1960s and early 1970s, have (as a number of critics note) been prescient of the broad direction of sport and of the rise of competitive reality television. This paper focuses specifically on The Long Walk, its critique of sport and how sporting contests manifest and reflect the broader society.

References to sport and games frequently crop up in the corpus of Stephen King, but they are not often the central focus. When it comes to sport, King predominately writes about baseball (when writing as himself). A life-long Red Sox fan, King gave full vent to his obsession in Faithful, co-authored with Stewart O'Nan, where they diary their shared hopes and fears, anxieties and depressions, related to the Red Sox' 2004 championship season. In an earlier non-fiction piece entitled "Heads Down," King chronicled the summer of his son's team's championship season in little league. In that, he discusses the meaning of baseball to the boys and their coaches, and how little league offers a formative experience in both dealing with competitive pressure and dealing with other human beings. ${ }^{1}$ In King's novel The Girl Who Loved Tom Gordon, baseball provides an anchor to the world for Trisha

\footnotetext{
${ }^{1}$ Stephen King, "Heads Down," New Yorker (1990). Reprinted in Nightmares and Dreamscapes (New York: Signet, 1994), 627-672.
} 
McFarlane when she is lost in the woods, and symbolically becomes a connection to higher powers and ultimately, the means of her survival. While Blockade Billy deals with a ballplayer who commits multiple murders, and $A$ Face in the Crowd (also co-written with O'Nan) creeps into horror with dead people appearing at ballgames, the vision of baseball in King's writing as a whole is overwhelmingly positive, with baseball as a venue for the expression of hopes and dreams, and a place of comfort, familiarity and solidity in society.

This matches with how baseball is typically portrayed in American literature. Baseball is seen, in popular culture and popular understandings, as tied to nature and the pastoral roots of American society, as a place where families and communities can come together through sport, and a cultural site that reflects many good things in American character. William Morgan argues that baseball is often approached with a moral understanding of excellence through hard work, social cooperation and fair play. At the same time, baseball literature tends to be very conservative-leaning, reinforcing traditional notions of masculinity, families, race relations, assimilation and meritocracy. ${ }^{2}$

The vision of sport and games in King's writing as Richard Bachman is nowhere near as positive as his own writing on baseball. King describes Bachman as being a "rainy day kind of guy." 3 He initially created the Bachman pseudonym to publish some of his early works without the star power of his own name. But he carried on writing (and has returned to writing) as Bachman as a literary voice that let him explore the places where "the rain is pretty much constant" and the good guys did not always win. ${ }^{4} \mathrm{He}$ describes Bachman as a state of mind, one of "low rage, sexual frustration, crazy good humor, and simmering despair." 5 So it is not surprising that Bachman's version of sport is radically different than King's take on baseball.

Tony Magistrale suggests that while Stephen King's work is extraordinarily popular with audiences and consequently lambasted as "unserious' by critics, it is often an expression of the major social and political anxieties of the time. ${ }^{6}$ For example, The Running Man can be taken as a cautionary tale about the power of television and a nation decaying from within. Since this novel is similar to The Long $W$ alk in its approach to entertainment and sport, I will briefly discuss it first. ${ }^{7}$ The Running Man is set in the year 2025, in a quickly degenerating east Coast city. Society is dominated by a television network that runs gameshows every night, to

\footnotetext{
2 William J. Morgan, "Baseball and the Search for an American Moral Identity," in Baseball and Philosophy, ed. Eric Bronson (Chicago: Open Court, 2004), 157-168. On how baseball is thought and written about by baseball fiction writers, see: Brooke K. Horvath and William J. Palmer, "Three on: An Interview with David Carkeet, Mark Harris and W.P. Kinsella," Modern Fiction Studies 33.1 (1987): 183-194. For an extended consideration of baseball literature, see David McGimpsey, Imagining Baseball: America's Pastime and Popular Culture (Bloomington, IN: Indiana University Press, 2000), and Timothy Morris, Making the Team: The Cultural Work of Baseball Fiction (Champaign, Il: University of Illinois Press, 1997). Morris is particularly critical of the conservative impulses in baseball literature.

${ }^{3}$ Stephen King, "The Importance of Being Bachman," in The Long Walk, (New York: Signet, 1999), viii.

${ }^{4}$ Stephen King, "The Importance of being Bachman," viii-ix, xii-xiii; Stephen King, "Why I was Bachman," in The Bacbman Books (New York: Signet, 1986), viii-ix. King published 5 books initially as Bachman before the pseudonym was blown - Rage (1977); The Long Walk (1979), Roadwork (1981), The Running Man (1982), and Tbinner (1984). He has since published two books as Bachman, The Regulators in 1996 as a literary stunt while co-publishing Desperation under his own name, and Blaze (2007) as a "trunk novel" to support his Haven Foundation for freelance artists with a disability.

${ }^{5}$ Stephen King, "The Importance of being Bachman," vii.

${ }^{6}$ Tony Magistrale, Hollywood's Stephen King, (New York: Palgrave Macmillan, 2003), 149.

${ }^{7}$ For an in-depth analysis of the Running Man novel, and the later film adaptation, see Douglas W. Texter, “"'A Funny Thing Happened on the Way to the Dystopia”: The Culture Industry's Neutralization of Stephen King's The Running Man," Utopian Studies 18 (2007), 43-72.
} 
entertain the middle class and control the poor from whom it draws its contestants. Two popular shows are "Swim with the Crocs," and "Treadmill to Bucks" for contestants with weak hearts. The main contest is "The Running Man," where contestants receive a 12 hour head start, and then law enforcement officers and special network stalkers hunt them down. Contestants win if they can stay alive for 30 days, although no one ever has when the novel starts. To encourage audience participation, the public can report on seeing the runners and thereby win cash prizes.

The main protagonist, Ben Richards, is an unemployed working-class man whose family needs medicine and food. Richards eludes capture for just over eight days, and through receiving assistance from rebels who attempt to hide him, he discovers various ways that the Network is destroying the intellectual, moral and physical fabric of society. Douglas Texter goes so far as to suggest that The Running Man is "a very Marxist-oriented interrogation of the American superstructure." " Ultimately, it finishes when Richards high-jacks a plane and, mortally wounded, crashes it into the network tower, taking hundreds of network executives with him. This serves as a symbolic attack on the Network and broader social structures, but like in much science fiction, we do not know if the character's actions bring any hope of real change. King notes that this is a Richard Bachman version of the happy ending, showing how jaded his writing is under that pseudonym. ${ }^{9}$

Now we turn back to considering The Long Walk, which in tone and subject is quite linked to The Running Man. Efforts at ethical criticism will proceed in two directions: first, following Mary Devereaux and her notion of the "posited author," we shall look at the story itself. As she argues, "we read a narrative text as if it were written by an author who has produced the text in such a way as to prompt certain questions and provide the resources to begin to answer them." 10 This "posited author," who we create in the act of reading, offers a sense of literary purposiveness that we can interpret in terms of moral concerns. In this case, I am advocating that Bachman's (King's) purpose was to offer a critique of trends and problems in sport, by proposing death-sports in a dystopian nearfuture. Secondly, we shall also look for a "historical author," where we consider the author in the broader social context. Devereaux argues that the historical author is quite different from the posited author, as the former is a real-life person, and the latter an interpretation of the critic, which allows getting at a more moral understanding of the narrative. Still, there is much utility in looking at the historical author, as exemplified by Colin McGinn's analysis of Nabokov's writing of Lolita, where he is interested in the context the author wrote in, as well as moral and aesthetic concerns. ${ }^{11}$ In the case of The Long Walk, it needs to be situated in the historical time frame of the late 1960s and early 1970s when it was first written, and in contemporary works in the genre of science fiction that make similar criticisms of sport.

\section{The Long Walk as Future Sport}

Within the novel The Long Walk, an event of the same name (The Long Walk), is the major sport of its timeframe. It is fruitful here to consider philosophical definitions of sport and the characteristics that something being "sport" suggests. The two most commonly used definitions of sport are those proposed by Allen Guttmann and Bernard Suits. Guttmann's work has mostly taken root in the history of sport academic literature, where it is known as

\footnotetext{
${ }^{8}$ Ibid., 45.

${ }^{9}$ Stephen King, "The Importance of being Bachman," vii.

${ }^{10}$ Mary Devereaux, "Moral Judgments and Works of Art: The Case of Narrative Literature," Journal of Aesthetics and Art Criticism 62 (2004), 6.

${ }^{11}$ For example, see Colin McGinn, Ethics, Evil, and Fiction (Oxford: Clarendon Press, 1997), especially $92-122$.
} 
the "Modernization Thesis."12 Suits' work has been more prevalent in the philosophy of sport literature, and he and Klaus Meier engaged in a debate over a number of years about what defines play, games and sport. ${ }^{13}$ A recent article in the journal Quest that looked at whether or not electronic sports (or eSports) could be considered sport, condensed together the main characteristics of Guttmann and Suits' work. I am going to draw on this summary by Jenny and colleagues to discuss these two main theories, which share a number of similarities. ${ }^{14}$

Sport, in both of the seminal definitions, must involve physical skills where chance or luck is not the sole reason for winning. Guttmann points out there must be competition, which is somewhat of a given in Suits, tied to the use of the physical skills. Guttmann also suggests that sport should involve play (voluntary, intrinsic motivation), while the difference between play, games and sport was part of the debate in the philosophy literature. Both definitions suggest sport should be organized and governed by rules. Guttmann extends this to include rationalization of roles, bureaucratization of the organizing, quantification of the activity and record-keeping. Suits argues to be sport, the activity should have a broad following beyond the local, and achieve institutional stability where it has become formalized, expertise develops and coaches, officials and governing bodies emerge (i.e., deeper, more formal organization). To summarize briefly, "sport" includes physical skills, competition, play, organization, a broad following, and institutionalization. We will keep these characteristics in mind as we look at the structure and narrative in the novel The Long Walk, so that the way the title competition fits as a sport in its fictional society can be drawn out.

In The Long Walk (1979), it could be questioned whether the setting is a near future America or an alternative present. ${ }^{15}$ There are cues that some historical events were different. For example, searchlights along the road remind the narrator, Ray Garraty of historical images he saw of the "German air-blitz of the American East Coast during the last days of World War II" (The Long Walk, hereafter TLW, 383) ${ }^{16}$. Further, the New Hampshire governor is noted as a war hero who had stormed a German nuclear base in Santiago in 1953 (TLW, 415), so clearly some events of the past are different. A para-military organization runs society, with "the Major," who is described as a "society-supported sociopath" (TLW, 185) as its primary figurehead and public persona. In several places in the

\footnotetext{
12 Allen Guttmann, From Ritual to Record: The Nature of Modern Sports (New York: Columbia University Press, 1978).

${ }^{13}$ The most current version of Suits' definition of sport is: Bernard Suits, "The Elements of Sport," in Etbics in Sport, 2nd. Ed., ed. William J. Morgan (Champaign, IL: Human Kinetics, 2007), 9-19. This is based on earlier musings on games and sport. See: Bernard Suits, "What is a Game," Philosophy of Science 34 (1967): 148-156; "The Elements of Sport," in The Pbilosopby of Sport: A Collection of Essays, ed. R. Osterhoudt (Springfield, IL: Charles C. Thomas, 1973), 48-64. On the debates between Meier and Suits, see Klaus V. Meier, "Triad Trickery: Playing with Sports and Games," Journal of the Philosophy of Sport XV (1988): 11-30; Meier, "Performance Prestidigitation," Journal of the Philosophy of Sport XVI (1989): 13-33, and Suits, "Tricky Triad: Play, Games, and Sport," Journal of the Philosophy of Sport XV (1988),:1-9; Suits, "The Trick of the Disappearing Goal," Journal of the Pbilosophy of Sport XVI (1989): 112.

${ }^{14}$ Seth E. Jenny, R. Douglas Manning, Margaret C. Keiper, and Tracy W. Olrich, "Virtual(ly) Athletes: Where esports Fit Within the Definition of "Sport," Quest 69 (2017): 1-18. For a table summary, see p. 5 .

${ }^{15}$ Stanley Wiater, Christopher Goldman and Hank Wagner, The Stephen King Universe: A Guide to the Worlds of the King of Horror (Los Angeles: Renaissance, 2001), 394.

${ }^{16}$ The version of The Long $W$ alk being cited is at it appears in The Bachman Books (New York: Signet, 1986), 171-434.
} 
novel, "the Squads" are mentioned, as a military force and the fate for people who misbehave or are too political.

To buoy up the sagging spirits of the citizenry, an annual competition named "The Long Walk" is held. In this, 100 young men aged 14-19, walk across the state of Maine. "The Prize" for the winner at the end of the Walk, is essentially whatever they want. Competitors must stay above 4 Miles per hour or they get a warning. They get three warnings, although each hour they stay back above 4 miles per hour without subsequent warning, they earn one back. On the fourth infraction, they "get their ticket" and are eliminated. This satisfies a number of criteria for being a sport - competition, organization and rules, and physical endurance being the determining factor. The wrinkle with the Long Walk, where the science fiction and critical elements come in, is that "getting their ticket" means being shot dead by the soldiers following in armored vehicles who monitor the competitors' speed. Ergo, the last man alive (literally), wins. All of this while television networks and large crowds watch.

The story is told from the perspective of one of the walkers, a young man from Maine named Ray Garraty. Much of the context of the society and the Long Walk's place within it is shown through Ray's thought-process, or flashbacks he has while walking. Garraty forms loose friendships with a number of the other walkers, whose stories get told through conversations. As time wears on and the walkers wear down, Garraty pontificates more about the meaning of the Walk and the meaninglessness of life. In the end, close to physical and mental collapse, he becomes convinced there can be no real winner.

The connection of the Long Walk to sport is made in several of ways. For example, a number of the competitors are portrayed as engaging in, or discuss, various strategies they plan to employ. Garraty's main rival, a boy named Stebbins, is seen constantly walking at the back of the pack, testing the limits of how slow he can go and conserving energy (TLW 187-188). Another boy named Barkowitz stops early on to tie a shoe unnecessarily, pointing out it allows him to take a break (TLW, 189). Garraty and Stebbings are seen frequently trying to psych each other out through trash-talking and gamesmanship, until near the end when they are among the few left. The competitors display awareness of a number of records from previous walks, including "the longest distance a full complement has ever covered-7 3/4 miles" (TLW, 191, 194), and that only 6 previous Long Walks have ended over the state line in New Hampshire, and one in Massachusetts. That fact is presented with a sporting simile — "experts say that was like Hank Aaron hitting seven hundred and thirty home runs, or whatever it was... record that would never be equaled" (TLW, 204). Sporting metaphors and similes crop up frequently, including baseball references like having three strikes, notions of rabbits and greyhounds, and descriptions of walkers looking like football players on the field, or punchy boxers.

At one point, Stebbins notes that "the Long Walk is the national pastime, after all," (TLW, 298), which is underscored by mass media attention, description of community support for the walkers, and profuse gambling. Such elements point to the Long Walk having a broad following, and various forms of institutionalization. Garraty thinks about getting into the Walk from the pool of applicants as an honour, and reflects on the testimonial dinner and Ladies Tea thrown in his honor before it began (TLW, 375; 380). Many of the Walkers discuss their memories of seeing previous Walks on television or in person, and how much of a spectacle it becomes. When the walkers turn onto the Maine Turnpike, there is a color guard and a 400 gun salute (TLW, 350-351) and Augusta is described as a "once-a-year city of crazy revelers, a party-down city full of a million boogying drunks and cukoo birds and out-and-out maniacs... They had heard Augusta and seen Augusta long before they had reached Augusta" (TLW, 383).

The only element of the definitions of sport that the Long Walk does not meet is the idea of play. There are few playful aspects when it is literally a life-and-death competition. 
However, "play" is possibly the least agreed upon aspect of the philosophical definitions of sport. As Angela Schneider has pointed out, there are many instances of sport that are not necessarily playful. According to her criticisms, being playful is a lusory attitude and not a given condition for an instance of sport, and inclusion of play as a requirement for sport may be a categorical error. She uses the example of the Olympics in the Cold War period (which is relevant to the time frame when The Long Walk was written), where the athletes are certainly doing sport, but not playing. ${ }^{17}$ And this is where the critique of society comes in for The Long $W$ alk. Although it has no elements of play, this is sport, the sport, for the fictional society that King has created.

The Long Walk frequently details the obsession and the blood-lust of fans in the crowd. Spectators cheer, gamble, and fight over the walkers' food tubes and cast-off clothing. Being from Maine, Garraty constantly sees signs and other forms of support from the crowd, and starry-eyed girls swoon over him. When Garraty has to defecate, there are flashbulbs and all kinds of people drawing attention to him. He figures it will end up as a souvenir on someone's mantelpiece (TLW, 355). The crowds start out very small in northern Maine, with just a smattering of locals and families, but swells as time goes on. For Garraty, the crowd becomes a faceless mass, an entity unto itself that starts with a capital "C," Crowd - "there was a swelling redness in that sound of Crowd. A hunger that was numbing." He sees the town itself as being swallowed up -

Only Crowd, a creature with no body, no head, no mind. Crowd was nothing but a Voice and an Eye, and it was not surprising to that Crowd was both God and Mommon. ... Crowd was to be pleased. Crowd was to be worshipped and feared. Ultimately, Crowd was to be made sacrifice unto (TLW, 384).

Demonstrating the novel's indications of societal decline, as the Crowd swells and the attention and spectacle ramp up, the deaths of the competitors are treated differently. The early deaths are treated with an aesthetic of violence, much like critics like Margaret Ervin Bruder and Jay Schneider advocate for in certain films - the violence is portrayed in extreme detail, evoking emotion and almost taking on aesthetic elements. ${ }^{18}$ The death of the first walker, named Curley, is drawn out over several pages as he fights off a charley-horse in his leg, and seems to shock everyone:

the crowd gasped as if they hadn't known this was the way it was, and the Walkers gasped, as if they hadn't known, and Garraty gasped with them, but of course he had known, of course they had all known, it was very simple, Curley was going to get his ticket.

Curley's death and the way his body falls is described in intense detail, and the distressed reaction of a number of people in the crowd is depicted. However, the crowd ahead hears that someone got their ticket, and cheers louder (TLW, 197-201). As the Walk wears on, and the walkers wear down, and death becomes frequent, the death of competitors becomes almost mundane. Late in the novel, a number of walkers have "gone down within

\footnotetext{
${ }_{17}$ Angela J. Schneider, "Fruits, Apples and Category Mistakes: On Sport, Games and Play," Journal of the Pbilosophy of Sport XXVIII (2001): 151-159.

${ }^{18}$ Margaret Ervin Bruder, "Aestheticizing Violence, or How to do Things with Style," Postmodern Papers 1998, http://www.gradnet.de/papers/pomo98.papers/mtbruder98.htm (accessed December 7, 2018); Steven Jay Schneider, "Killing in Style: The Aestheticization of Violence in Donald Cammell's White of the Eye," Scope - An Online Journal of Film and Television Studies (2004), https://web.archive.org/web/20040619114211/http://www.nottingham.ac.uk/film/journal/articles/ killing-in-style.htm (accessed December 7, 2018).
} 
themselves," and they look to Garraty like the walking dead. As he watches impassively, "three of them went down at once. The mouth of the crowd roared and belched anew with enthusiasm as the bodies spun and thumped like chunks of cut cordwood" (TLW, 416). But Garraty could summon no emotion.

Direct analogies are made to ancient Rome and the bloodlust of the crowd. At one point, a walker states that when he cannot go on any further, he will dive into the crowd in the hopes that the soldiers will not shoot. Garraty replies that he thinks the crowd will throw him back so they can watch him bleed (TLW, 359). Garraty's closest companion on the Walk, McVries, points out that the crowd "are the smart ones. They're not getting thrown to the lions. They're not staggering along and hoping they won't have to take a shit with two warnings against them." He points out that the crowd lives on their dying- "The old Romans used to stuff each other after the gladiatorial matches. That's entertainment Garraty. It's nothing new." (TLW, 295-296).

\section{Historical Context for the Novel and Societal Critique}

King offers readers a novel that predicts near-future sports as violent spectacle with many analogies to ancient Rome. We could take this as escapist, inconsequential storytelling from a prolific writer who goes on the make a career on scaring people in the horror genre. However, we might consider some of the proposals put forward by literary critics about science fiction, which take a more serious look at what it potentially offers. Patrick Parrinder suggests that science fiction is not merely a mirror of contemporary society, but is essentially oriented toward social criticism, and a source of active commentary on society and its attitudes. ${ }^{19}$ As Alexandra Aldridge wrote, "Dystopian novelists nearly always are jarred into writing by the particularity of their negative perspective on contemporary history, and begin their work by extrapolating from this perspective." 20 In writing The Long Walk, King is responding to trends in sport, television and spectacle and the broader society at the time. This moves us from considering just the posited author-who offers social critique of sport and society - to the historical author, who is writing that critique about the particular time-frame.

Although published in 1979 and 1982, King wrote The Long Walk and The Running Man in a much earlier period. King notes that the earlier Bachman books were written by a "young man who was angry, energetic, and deeply infatuated with the art and craft of writing." ${ }^{21}$ He wrote The Long Walk as a first novel while still a freshman in college in 1966, and indicates that he completed The Running Man over a single weekend in 1971; it was later published with virtually no changes. ${ }^{22}$ Thus, these novels are tied to the period of the late 1960s and early 1970s.

Critics relate these novels, and their relentless portrayal of largely meaningless death, to the Vietnam-era United States. Both The Long Walk and The Running Man serve as an analogy for American society at the time; as Michael Collings argues, they "are about contemporary states-contemporary political, social and commercial realities." 23 Both novels picture grim, dystopian societies where despite the games, you cannot win, cannot beat the system, at least if you come from the lower classes. The novels are not focused on winning or losing the games, because ultimately, life is hopeless, even if winning seems

${ }_{19}$ Patrick Parrinder, Science Fiction: Its Criticism and Teaching (London: Metheun, 1980): 30, 72.

20 Alexandra Aldridge, "Origins of Dystopia: When the Sleeper Wakes and We," in Clockwork Worlds:

Mechanized Environments in SF. ed. Richard D. Erlich and Thomas P. Dunn. (Westport, CT:

Greenwood, 1983), 72.

${ }^{21}$ Stephen King, "The Importance of Being Bachman," vii.

22 Stephen King, "Why I was Bachman," xii.

${ }^{23}$ Michael R. Collings, Stephen King as Richard Bachman (Washington: Starmont, 1985), 14-15. 
possible. ${ }^{24}$ The randomness of death and the frequent allusion to game shows, to luck or chance being the determinant of whether one lives or dies, is analogous to the "lottery" of the draft and military service in Vietnam..$^{25}$

The sport-like competitions in the Bachman books combine the trappings of sport with game show elements into a form of near-future "post-sport," with losing bringing the ultimate consequences. Some would suggest that sport in/and human societies go through a "civilizing process" that moves away from violence to practices that are safer, more organized and rule-bound. ${ }^{26}$ However, sport in the late 1960s and 1970s offered much for criticism, and much that would suggest ever-more spectacular and violent media events. Politics, commercialization, and violence on and off the field raised the spectre of the Roman Colloseum with many observers. The world entered the "Cold War Olympics" era, ${ }^{27}$ where highly politicized sports became emblematic of ideological systems and opposing societies. Vice-President Hubert Humphries' 1966 call for a "great sport effort" to prove America could surpass the Soviets in developing athletes emphasized the state of affairs. ${ }^{28}$ Rather than real war, with its nuclear consequences, sport became, as attributed to George Orwell, war minus the shooting.

The rise of television sport in the 1960s promoted an intense commercialization of elite level sport in the United States and elsewhere. With the value of professional sports to television, the "Battle of the Networks" to gain more sport content and outdo each other in terms of spectacle, lasted from the mid-1960s until the 1980s. ${ }^{29}$ This drove up profits and player salaries, and encouraged the move of college football and basketball to big-time sports, with blue chip athletes and all sorts of recruiting violations. Professional football took special prominence in the late $60 \mathrm{~s}$ and early $70 \mathrm{~s}$, largely thanks to the creation of Monday Night Football by Roone Arledge at ABC. ${ }^{30}$ This trend towards hyper-mediation of sport fed into rising tides of violence-sport became more instrumentally violent since it was worth more, and sporting violence became a media spectacle in its own right.

On elite football fields and basketball courts, players became larger, quicker and more athletic, adding to the impact of colliding bodies. ${ }^{31} \mathrm{~A}$ culture of violence developed in sport, where dominating an opponent through physical violence became an accepted strategy in a number of professional leagues. ${ }^{32}$ For example, the Philadelphia Flyers, a National Hockey League expansion team, won two titles while known as "the Broad Street Bullies." The 1970 s saw the birth of "the enforcer," in hockey, a player whose job and sole reason for being on teams, was to fight and protect his team's stars from attack. Attitudes (and nicknames) of players at the time are exemplified by auto-biographies of players active in

\footnotetext{
${ }^{24}$ Ibid., 103-105.

${ }^{25}$ Stanley Wiater, Christopher Goldman and Hank Wagner, The Stephen King Universe: A Guide to the Worlds of the King of Horror, 395-396.

${ }^{26}$ For example, see Norbert Elias and Eric Dunning, Quest for Excitement: Sport and Leisure in the Civilizing Process (Dublin: University College Dublin Press, 1986).

${ }^{27}$ Robert A. Mechicoff and Steven G. Estes, A History and Pbilosophy of Sport and Physical Education (Boston: McGraw-Hill, 1998), 364-411.

${ }^{28}$ Douglas A. Noverr and Lawrence E. Ziewacz. The Games They Played: Sports in America, 1865-1980 (Chicago: Nelson-Hall, 1983), 245.

29 Randy Roberts and James Olson, "The Roone Revolution," in Sport in America: From Wicked Amusement to National Obsession, ed. David Wiggins (Champaign, Il: Human Kinetics, 1995), 271-272.

${ }^{30}$ Benjamin D. Rader, American Sports: From the Age of Folk Games to the Age of Television (Upper Saddle River, NJ: Prentice Hall, 2004), 269-275.

${ }^{31}$ Douglas A. Noverr and Lawrence E. Ziewacz. The Games They Played: Sports in America, 1865-1980, 256.

32 David W. Zang, Sports Wars: Atbletes in the Age of Aquarius (Fayettville: University of Arkansas Press, 2001), 82-85.
} 
the 1960s and 1970s, such as hockey player Dave Schultz (The Hammer: Confessions of a Hockey Enforcer) and football players Conrad Dobler (They Call Me Dirty) and Jack Tatum (They Call Me Assassin). Significant episodes of violence beyond the context of the game appeared in this period, even in supposedly non-contact college sports like basketball. David Zang describes the behavior of a number of college players and coaches, noting that "sports were no longer a world apart, but rather one more brutal part of a world that seemed to be seething with rage and frustration." 33

Fan behaviors also demonstrated trends towards violence and confrontation. In Europe, soccer hooliganism hit a new peak in the late 1960s and early 1970s, or at least received large amounts of media coverage for the first time. Between 1967 and 1971, fans in Detroit, New York, Pittsburgh and Columbus, Ohio, went on massive rampages that cost millions of dollars in property damage. Beyond the riots and fights, fans in the stands and at home fed into and off of the trend towards on-field violence, encouraging players like the crowds of Rome (or Crowd of the Long Walk). Fan behaviors also tended towards the eccentric and the obsessive, with extreme team and player loyalties, massive sports-oriented consumption, and at games, attempts to attract television cameras to themselves through signage, stripping and pitch invasions. ${ }^{34}$ Further, in the bid for the sports audience, the networks began to cover a number of "pseudo-sports" in the 1960s, such as arm wrestling and log rolling. It was a short step to adding so-called "trash sports" to their rosters in the 1970s, new forms of sportized media spectacles like roller derby and the "Battle of the Superstars," pitting athletes, and later celebrities, against each other in a series of sport-like competitions. ${ }^{35}$

Given all of these trends, it is not difficult to determine why criticisms of the sports world began to show up in literature and film in the 1960s and 1970s. As David Zang argues, 1960s counterculture criticized sport, especially football, as a promoter of traditional conservative values and an emblem of an "imperialistic and bullying society." 36 Given that King wrote The Long Walk and The Running Man in this period, and took part in campus protests, the novels need to be seen as tied to criticisms of sport of the time, especially televised sport.

A number of writers and filmmakers produced similar, highly critical work about sport contemporaneously with King/Bachman's version of future sports. In more mainstream writing, Peter Gent's 1973 novel North Dallas Forty (and film adaptation of the same name) exposed the underbelly of professional football in the United States, detailing its violence and drug cultures, and use and abuse of players' bodies. However, many of the more compelling examples from this period, like the Bachman books, criticize the present by projecting the near-future. One key work was Norman Spinrad's short story "The National Pastime," also written in 1973, which foresaw the development of "Combat Football," where fighting and the death count among the spectators mattered as much as the action on the field. The best known envisionment of future sports appeared in William Harrison's 1973 short story "Rollerball Murder," converted to the 1975 cult film Rollerball. The story and film mirror The Long Walk in suggesting a popular, extremely violent form of sport as an opiate for the masses in a technocratic, dystopian society. Citing these works is not to

\footnotetext{
33 Ibid., 86.

34 David W. Zang, Sports Wars: Athletes in the Age of Aquarius, 85-94; Benjamin D. Rader, American Sports: From the Age of Folk Games to the Age of Television, 253.

35 Randy Roberts and James Olson, "The Roone Revolution," 280-281.

${ }^{36}$ David W. Zang, Sports Wars: Athletes in the Age of Aquarius, 81-82.
} 
suggest that they directly influenced King's writing, ${ }^{37}$ but to point out a sensibility among cultural creatives at the time, when looking at the direction of the world of sport. Generally, writers and filmmakers of the 1960s and 70s saw no abatement of the trends towards politics, violence and fan extremism, and ultimately predicted a return to gladiatorial bloodsports.

The vision of future sport in The Long Walk and other similar works of the time do not seem likely to come true at this point, at least not in the sports world, thanks primarily to rule changes. Writing as early as 1985, shortly after the period being discussed, David L. Vanderwerken noted that he could not "think of one rule change in recent years that does not reduce player risk, or that rewards violent play." 38 This has possibly become more true since then, perhaps an example of the civilizing process at work. Most mainstream professional and elite sports have introduced rules to protect players, in part due to the recognition that players are as much the raw material of sport as they are the spectacle produced. Rule changes such as in the National Hockey League (NHL) in 2005 are designed to open up play and reduce some of the roughness, although that may have led to more open-ice hits and the rise of concussions in the sport. Stadiums have become safer for fans, as cities and teams have put in reasonably effective security measures to control and protect spectators and minimize the potential for clashes.

Having said that, it is still quite clear that athletes are willing to sacrifice their bodies and health for their sports careers, shown in both the normalization of pain and injury and the rise of doping in sport. The commercialization and mediatization of sport continues apace, but the trashsports of the 1970s have mostly disappeared, replaced as TV filler by more serious (if in some cases, no less trivial) competitions like triathlons, the X-Games and lumber sports. Players have continued to get bigger and stronger, notably in hockey. Bigger bodies mean heavier collisions, with increased violence, which might also explain the rise of concussions in hockey. Leagues such as the NHL, the National Football League and the Canadian Football League have been slow to recognize the concussion crisis, and in some cases outright denied the connection for a long time. And there is a deep nostalgia for the violence of the past, as evidenced by a spate of football hooligan memoirs and films in the 2000s in England, and a recent upswing in hockey enforcer biographies in North America. ${ }^{39}$ Further, sport-related riots continue to occur every few years, at least, in North America.

Despite many positive changes in sport, the critique of television and society in works such as The Long Walk and The Running Man remains relevant, although not necessarily to the sports world. Work such as seen in these Bachman books is scarily prescient, not of the direction that sport has taken, but of the rise of reality television. Reality television seems the venue where Bachman's post-sport nightmares might most likely become "reality." 40

\footnotetext{
${ }^{37}$ Not that precedence matters for the point made here, but The Long Walk_and The Running Man predate much of this sort of material, with writing dates of 1966 and 1971. The ideas in these stories could in turn be related to traditions in dystopian science fiction, and more mainstream writing like Richard Connell's "The Most Dangerous Game" (1924) and its many adaptations.

${ }^{38}$ David L. Vanderwerken, "Roller Ball: Sport and Society in the Future," Arete: The Journal of Sport Literature II (1985): 43.

${ }^{39}$ On football hooligans, see Steve Redhead, "Hit and Tell: a Review Essay on the Soccer Hooligan Memoir," Soccer \& Society 5 (2004): 392-403. For examples of hockey enforcer biographies, see John Branch, Boy on Ice: The Life and Death of Derek Boogard (Toronto: HarperCollins, 2014); Georges Laraque, Georges Laraque: The Story of the NHL's Unlikeliest Tough Guy, (Toronto: Viking, 2011); Chris Nilan, Fighting Back: The Chris Nilan Story (Toronto: HarperCollins, 2013).

${ }^{40} \mathrm{I}$ am certainly not claiming to be the first to make this link from King to reality TV. There are more critics who have mentioned this than could be listed, and reviews of literature and film versions of The Running Man on the Internet Movie Data Base and Amazon are rife with people making this very point. The sport connections, however, are not as well stressed.
} 
Indicating the public's taste for it, reality television is the fastest growing and diversifying genre of television programming, having become a staple of television programming. ${ }^{41}$ The competitive gameshow form itself exhibits a variety of styles; we have the Big Brother format where people are locked in a house together, the road trip style, like The Amazing Race, where contestants travel to/race through exotic locales, and the castaway style like Survivor, all with contrived physical and mental challenges while the cameras roll.

An important aspect of reality television is its participatory nature. In The Long Walk, the crowd oohs and aahs over the death spectacle in front of them, while in The Running Man, the public participates, by reporting on sightings and calling in the hunters. In reality television, the audience is an integral part of the process for many shows, voting on who stays or goes, who wins or loses. As media critic Simon Hoggart more than aptly questions,

When will contestants, instead of being sent home and allowed to tell us how they were carved up by their fellow performers, simply be executed? "If it's Darren you want to see with his limbs roped to four hungry Percherons who are whipped in opposite directions until he dies screaming and crows descend to feed on his fresh, hot entrails, dial 0847 555511. Calls cost 50p per minute..." I don't see why it shouldn't happen. As Gary Gilmore and Timothy McVeigh have proved, lots of people are happy to die in public if it makes them famous. The notoriously mean television companies wouldn't even need to fork out prize money. ${ }^{42}$

Thinking about the trends on the competitive gameshow forms of reality television makes Bachman's vision of things seem much less far-fetched.

In his analysis of the fate of the critique Bachman put forth in The Running Man, Douglas Texter asserts that the culture industry neutralized the critique by subverting and incorporating the concept. When it came out that Bachman was King, sales of all the Bachman books increased exponentially, and The Running Man was adapted into an action film that was a vehicle for Arnold Schwarzenegger. Texter notes that the violence in the film is hardly frightening, and there was a conservative political element that criticizes big government, rather than big media. Then, The Running Man became reality TV. In 2001, the American Broadcasting Corporation licensed a show called "The Runner" to actors Ben Affleck and Matt Damon. Its premise was that contestants would get one million dollars if they could avoid "hunters" for one month. The events of September 11 caused the show to be cancelled as being in poor taste. But Affleck and Damon did produce the show in 2016, on Verizon's Go90 mobile video network. Being on a mobile platform made it easier for audience members to report in on the contestant's whereabouts for prizes. ${ }^{43}$ Nobody was killed, but otherwise, science fiction critique became popular culture reality. I hesitate to say we will ever see a Long Walk, but early readers of The Running Man likely said the same thing.

Perhaps, like the world of sport, the trend towards increasing violence will reverse. Perhaps not. Reality television, unlike sport, started out as spectacle first, so the acceleration of the spectacularization and its effects will not likely diminish. As well, unlike sport, the potential "talent pool" for competitors is virtually unlimited.

Written in the 1960s and 1970s, King's (Bachman's) The Long Walk and The Running Man envisioned a nightmarish near-future where the sports and games of society had returned to

\footnotetext{
${ }^{41}$ Sujata Moorti and Karen Ross, "Reality Television: Fairy Tale or Feminist Nightmare? Feminist Media Studies 4 (2004): 203-205.

${ }^{42}$ Simon Hoggart, "Illusions and Reality." Spectator [London], 2 June, 2001: 57.

${ }^{43}$ Matthew Dessem, "Ben Affleck and Matt Damon's New Reality Show Is Basically the Stephen King Novel The Running Man," Slate, 16 March 2016.
} 
pseudo-gladiatorial deathsports for commercialized spectacle and distraction of the masses. These short novels display a deep concern for trends in sport and society in that time period. Scarily, many forms of reality television seem to function as spectator sport created in television's own image, a troubling concept. How far we continue to move towards Bachman's post-sport nightmares remains to be seen. Clearly, whatever happens, it will be seen, by the interested masses huddled around some form of screen.

\section{References}

Aldridge, Alexandra. "Origins of Dystopia: When the Sleeper Wakes and We. In Clockwork Worlds: Mechanized Environments in SF. ed. Richard D. Erlich and Thomas P. Dunn, 6384. Westport, CT: Greenwood, 1983.

Branch, John. Boy on Ice: The Life and Death of Derek Boogard. Toronto: HarperCollins, 2014.

Bruder, Margaret Ervin. 'Aestheticizing Violence, or How to do Things with Style,' Postmodern Papers (1998). http://www.gradnet.de/papers/pomo98.papers/mtbruder98.htm (accessed December 7, 2018).

Collings, Michael R. Stephen King as Richard Bachman. Washington, Starmont, 1985.

Connell, Richard. 'The Most Dangerous Game' Collier's, 19 January 1924.

Dessem, Matthew. 'Ben Affleck and Matt Damon's New Reality Show Is Basically the Stephen King Novel The Running Man.' Slate, 16 March 2016.

Devereux, Mary. 'Moral Judgments and Works of Art: The Case of Narrative Literature.' Journal of Aesthetics and Art Criticism 62 (2004): 3-11.

Dobler, Conrad and Vic Carucci. They Call Me Dirty. New York: Jove Books, 1989.

Elias, Norbert and Eric Dunning. Quest for Excitement: Sport and Leisure in the Civilising Process. Dublin: University College Dublin Press, 1986.

Gent, Peter. North Dallas Forty. William Morrow, 1973.

Guttmann, Allen. From Ritual to Record: The Nature of Modern Sports. New York: Columbia University Press, 1978.

Harrison, William. 'Rollerball Murder.' (1973). In A Literature of Sports. Ed. Tom Dodge, 919. Lexington, Mass.: D.C. Heath and Company, 1980.

Hoggart, Simon. 'Illusions and Reality.' Spectator [London]. 2 June, 2001, 57.

Horvath, Brooke K. and Palmer, William J. 'Three on: An Interview with David Carkeet, Mark Harris and W.P. Kinsella.' Modern Fiction Studies 33.1 (1987): 183-194.

Seth E., Jenny, Manning, R. Douglas, Keiper, Margaret C. and Olrich, Tracy W. 'Virtual(ly) Athletes: Where esports Fit Within the Definition of "Sport." Quest 69 (2017): 1-18.

King, Stephen. "Why I was Bachman." In The Bachman Books. New York: Signet, 1986. vxiii.

"Heads Down," New Yorker, 1990. Reprinted in Nightmares and Dreamscapes. New York: Signet, 1994, 627-672.

Desperation. New York: Viking, 1996.

The Girl Who Loved Tom Gordon. London: Hodder \& Stoughton, 1999. xiii.

"The Importance of Being Bachman." in The Long Walk. New York: Signet, 1999. v-

Blockade Billy. Forest Hill, Maryland: Cemetery Dance, 2010.

King, Stephen. [writing as Richard Bachman]. Rage. New York: Signet, 1977.

.The Long Walk (1979). Reprinted in The Bachman Books. New York: Signet, 1986. 171434.

Roadwork. New York: Signet, 1981.

The Running Man (1982). Reprinted in The Bachman Books. New York: Signet, 1986. 709-923. 
Thinner. New York: New American Library, 1984.

The Regulators. New York: Dutton, 1996.

Blaze. New York: Scribner, 2007.

King, Stephen, and Stewart O'Nan. A Face in the Crowd (ebook). New York: Simon \& Schuster Digital, 2012.

Laraque, George. Georges Laraque: The Story of the NHL's Unlikeliest Tough Guy. Toronto: Viking, 2011.

Magistrale, Tony. Hollywood's Stephen King. New York: Palgrave Macmillan, 2003.

McGimpsey, David. Imagining Baseball: America's Pastime and Popular Culture. Bloomington, IN: Indiana University Press, 2000.

McGinn, Colin. Ethics, Evil, and Fiction. Oxford: Clarendon Press, 1997.

Mechicoff, Robert A. and Steven G. Estes. A History and Pbilosophy of Sport and Physical Education. Boston: McGraw-Hill, 1998.

Meier, Klaus V. "Triad Trickery: Playing with Sports and Games." Journal of the Philosophy of Sport XV (1988): 11-30.

Meier, Klaus V. "Performance Prestidigitation." Journal of the Philosophy of Sport XVI (1989): 13-33.

Morgan, William J. "Baseball and the Search for an American Moral Identity.” In Baseball and Philosophy, ed. Eric Bronson, 157-168. Chicago: Open Court, 2004.

Moorti, Sujata and Karen Ross. "Reality Television: Fairy Tale or Feminist Nightmare?" Feminist Media Studies 4.2 (2004): 203-205.

Morris, Timothy. Making the Team: The Cultural Work of Baseball Fiction. Champaign, Il : University of Illinois Press, 1997.

Nilan, Chris. Fighting Back: The Chris Nilan Story. Toronto: HarperCollins, 2013.

Noverr, Douglas A. and Lawrence E. Ziewacz. The Games They Played: Sports in America, 1865-1980. Chicago: Nelson-Hall, 1983.

O'Nan, Stewart and Stephen King. Faithful: Two Diehard Fans Chronicle the Historic 2004 Season. New York: Scribner, 2004.

Parrinder, Patrick. Science Fiction: Its Criticism and Teaching. London: Metheun, 1980.

Rader, Benjamin D. American Sports: From the Age of Folk Games to the Age of Television. Upper Saddle River, NJ: Prentice Hall, 2004.

Redhead, Steve. "Hit and Tell: a Review Essay on the Soccer Hooligan Memoir." Soccer \& Society 5 (2004): 392-403.

Roberts, Randy and James Olson, "The Roone Revolution." In Sport in America: From Wicked Amusement to National Obsession. ed. David Wiggins. Champaign, Il : Human Kinetics, 1995.

Schneider, Angela J. "Fruits, Apples and Category Mistakes: On Sport, Games and Play." Journal of the Philosophy of Sport XXVIII (2001): 151-159.

Schneider, Steven Jay. "Killing in Style: The Aestheticization of Violence in Donald Cammell's White of the Eye," Scope-An Online Journal of Film and Television Studies, (2004).https://web.archive.org/web/20040619114211/http://www.nottingham.ac.uk/f $\mathrm{ilm} /$ journal/articles/killing-in-style.htm (accessed December 7, 2018)

Schultz, Dave and Stan Fischler. The Hammer: Confessions of a Hockey Enforcer. New York: Berkeley, 1983.

Suits, Bernard. "What is a Game?.” Philosophy of Science 34 (1967): 148-156. . "The Elements of Sport." In The Philosophy of Sport: A Collection of Essays, ed. R.

Osterhoudt, 48-64. Springfield, IL: Charles C. Thomas, 1973. 9 . . "Tricky Triad: Play, Games, and Sport." Journal of the Philosophy of Sport XV (1988): 19. 12.

"The Trick of the Disappearing Goal." Journal of the Philosophy of Sport XVI (1989), 1- 
. “The Elements of Sport.” In Ethics in Sport, 2nd. Ed., ed. William J. Morgan, 9-19. Champaign, IL: Human Kinetics, 2007.

Spinrad, Norman. “The National Pastime.” (1973). In Future Pastimes. ed. Scott Edelstein, 27-45. Nashville, Aurora, 1977.

Tatum, Jack. They Call Me Assassin. Everest House, 1980.

Texter, Douglas W. ““'A Funny Thing Happened on the Way to the Dystopia”: The Culture Industry's Neutralization of Stephen King's The Running Man," Utopian Studies 18 (2007): 43-72.

Vanderwerken, David L. "Roller Ball: Sport and Society in the Future." Arete: The Journal of Sport Literature II.2 (1985): 39-45.

Wiater, Stanley, Christopher Goldman and Hank Wagner. The Stephen King Universe: A Guide to the Worlds of the King of Horror. Los Angeles: Renaissance, 2001.

Zang, David W. Sports Wars: Atbletes in the Age of Aquarius. Fayetteville: University of Arkansas Press, 2001. 